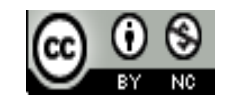

Jurnal Pendidikan Matematika Indonesia is licensed under

A Creative Commons Attribution-Non Commercial 4.0 International License.

\title{
MeningkatKan Literasi Matematis Mahasiswa Calon Guru SEKolah DASAR DALAM MEMBELAJARKAN MATEMATIKA
}

\author{
Olenggius Jiran Dores ${ }^{1)}$, Beni Setiawan ${ }^{2)}$ \\ 1) STKIP Persada Khatulistiwa, Sintang, Indonesia \\ E-mail:olenggius@gmail.com \\ ${ }^{2}$ STKIP Persada Khatulistiwa, Sintang, Indonesia \\ E-mail: benisetiawan1892@gmail.com
}

\begin{abstract}
Abstrak. Kemampuan literasi siswa indonesia sangat memprihatinkan yakni $79 \%$ siswa Indonesia berada pada level rendah. Sedangkan hasil studi internasional yang dilakukan oleh Programme for International Student Assessment (PISA) pada 72 negara di dunia tahun 2015, menyatakan bahwa skor rata-rata literasi matematika siswa Indonesia adalah 386 masih dibawah rata - rata. Guru harus memiliki keterampilan yang baik yang sedini mungkin sebelum melaksanakan pembelajaran matematika pada siswa. Tanpa terkecuali para mahasiswa calon guru Sekolah Dasar. Adapun tujuan penelitian ini adalah meningkatkan literasi matematis mahasiswa calon guru sekolah dasar dalam membelajarkan matematika. Metode penelitian ini adalah pedagogic action research dengan tahapan think, act, look. Berdasarkan hasil analisis data dapat disimpulkan bahwa (1) kemampuan literasi matematis awal mahasiswa masih rendah dengan rata-rata hasil tes 50,5 ; (2) pembelajaran matematika berbasis literasi berjalan dengan baik; (3) terdapat peningkatan kemampuan literasi matematis mahasiswa sebesar 26,9 ; (4) pembelajaran matematika berbasis literasi berkontribusi terhadap kemampuan literasi matematis mahasiswa
\end{abstract}

Kata Kunci: Literasi Matematis, Matematika, Mahasiswa

\section{Pendahuluan}

Literasi matematis dalam PISA adalah fokus kepada kemampuan peserta didik dalam menganalisa, memberikan alasan, dan menyampaikan ide secara efektif, merumuskan, memecahkan, dan menginterpretasi masalah-masalah matematika dalam berbagai bentuk dan situasi. Penilaian yang digunakan adalah fokus kepada masalah-masalah dalam kehidupan nyata, diluar dari situasi atau masalah yang sering di bahas di kelas. Di dalam kehidupan nyata, kita sering menghadapi stuasi ketika berbelanja, melakukan perjalanan, memasak, masalah keuangan, menganalisis situasi politik, dan hal-hal lain dimana penggunaan quatitative or spatial reasoning atau kemampuan matematika lainnya merupakan alat bantu yang menjelaskan atau memecahkan suatu masalah. Lebih lanjut NCTM menyatakan bahwa terdapat lima kompetensi dalam literasi matematis yaitu pemecahan masalah matematis (mathematical problem solving), komunikasi matematis (mathematical communication), penalaran matematis (mathematical reasoning), koneksi matematis (mathematical connection), dan representasi matematis (mathematical representation).
Kemampuan literasi siswa indonesia sangat memprihatinkan yakni $79 \%$ siswa Indonesia berada pada level rendah (Tjalla, 2010). Sedangkan hasil studi internasional yang dilakukan oleh Programme for International Student Assessment (PISA) pada 72 negara di dunia tahun 2015, menyatakan bahwa skor ratarata literasi matematika siswa Indonesia adalah 386 dan masih dibawah rata-rata (OECD, 2016).

Rendahnya hasil pemetaan kemampuan siswa khususnya kemampuan literasi matematis menjadi bahan evaluasi bagi pemerintah sebagai pengambil kebijakan serta guru sebagai ujung tombak dalam pelaksanaan pendidikan nasional. Pelaksanaan pendidikan nasional akan berjalan dengan baik bilamana kurikulum dan tenaga pendidik saling bersinergi secara optimal.

Dalam UU No. 20 Tahun 2003 mengenai Sistem Pendidikan Nasional Pasal 37 menyatakan dengan tegas bahwa matematika adalah salah satu mata pelajaran yang harus diajarkan kepada siswa pada jenjang pendidikan dasar dan menengah. Hal ini disebabkan matematika merupakan ilmu yang melandasi berbagai jenis disiplin ilmu lainya termasuk ke dalamnya adalah ilmu alam dan ilmu sosial. Oleh karenanya, guru memegang peran penting dalam membelajarkan matematika.

Guru harus memiliki keterampilan yang baik yang sedini mungkin sebelum melaksanakan pembelajaran matematika pada 
siswa. Tanpa terkecuali para mahasiswa calon guru, khususnya calon guru Sekolah Dasar (SD). Literasi matematis sangat penting pada kehidupan setiap individu, karena berkaitan dengan tugas dan pekerjaan kehidupan dalam sehari-hari. Pemanfaatan literasi matematis tidak hanya sekeder pemahan aritmetik, namun lebih kepada penguasaan pemecahan masalah yang membutuhkan penalaran serta harus mammpu menggunakan logika dalm setiap penegambilan keputusan (Kenedi \& Helsa, 2017). Maka dari itu, kemampuan literasi matematis harus diberikan kepada mahasiswa calon guru agar mereka dapat mengapilkasinya dalam kehidupan mereka, terkhusus ketika akan terjun kemasyarakat sebagai tenaga pendidik dan berimplikasi pada meningkatnya kemampuan literasi matematis siswa - siswa di Indonesia. Jika mahasiswa tidak dibekali kemampuan meliterasi matematis sejak dibangku kuliah, alhasil dalam membelajarkan matematika pada siswa akan cenderung biasa - biasa saja dan tidak akan memberikan dampak yang signifikan dalam pengembangan kemampuan literasi matematis siswa di Indonesia.

Berdasarkan pada hasil studi pendahuluan berupa pemberian tes saat matrikulasi pada mata kuliah Konsep Dasar Matematika SD pada mahasiswa kelas A9, B9, C9 dan D9 Program Studi Pendidikan Guru Sekolah Dasar (PGSD) STKIP Persada Khatulistiwa Sintang, kelas D9 merupakan kelas dengan kemampuan literasi matematis terendah. Dengan jumlah mahasiswa 41 orang, diperoleh fakta bahwa mahasiswa kesulitan dalam pemecahan masalah matematis, komunikasi matematis, penalaran matematis, koneksi matematis, dan representasi matematis dengan rata - rata skor 52,3.

Berdasarkan pemaparan diatas, kami tim peneliti berkomitmen untuk "Meningkatkan Literasi Matematis Mahasiswa Calon Guru Sekolah Dasar Dalam Membelajarkan Matematika". Kemampuan literasi matematis siswa seyogyanya berasal dari guru yang membiasakannya. Guru yang mampu membiasakan siswanya untuk ber-literasi matematis adalah guru yang memahami bagaimana meliterasi matematis. Oleh karena itu, tujuan dari penelitian ini adalah meningkatkan literasi matematis mahasiswa calon guru sekolah dasar dalam membelajarkan matematika.

\section{MEtode PENELITIAN}

Adapun bentuk penelitian ini adalah penelitian tindakan pedagogis (pedagogic action research). Penelitian tindakan adalah suatu tindakan penelitian dalam konteks kelas untuk memecahkan masalah - masalah pembelajaran yang dihadapi oleh guru, dengan cara memperbaiki proses dan hasil pembelajaran serta faktor - faktor yang mempengaruhinya (Bistari, 2015). Sedangkan menurut Tampubolon (2014) menyatakan bahwa penelitian tindakan adalah suatu penelitian reflektif yang bersiklus yang dilakukan oleh pendidik (guru dan dosen) untuk memecahkan masalah pendidikan. Senada dengan hal tersebut, Sukardi (2015) menyatakan bahwa penelitian tindakan mempunyai karakteristik diantaranya (1) peneliti dimungkinkan untuk memberikan perlakuan berupa tindakan terencana, (2) langkah - langkah penelitian selalu dalam bentuk siklus, (3) adanya langkah reflektif baik sebelum maupun sesudah penelitian.
Adapun bentuk penelitian ini adalah penelitian tindakan pedagogis (pedagogic action research). Penelitian tindakan pedagogis adalah suatu penelitian tindakan yang dilakukan untuk memecahkan masalah - masalah pembelajaran dengan cara memperbaiki proses pembelajaran disertai bimbingan atau layanan pada peserta didik guna meningkatkan hasil pembelajaran. Penelitian tindakan pedagogis dilakukan secara bersiklus dengan rancangan sebagai berikut:

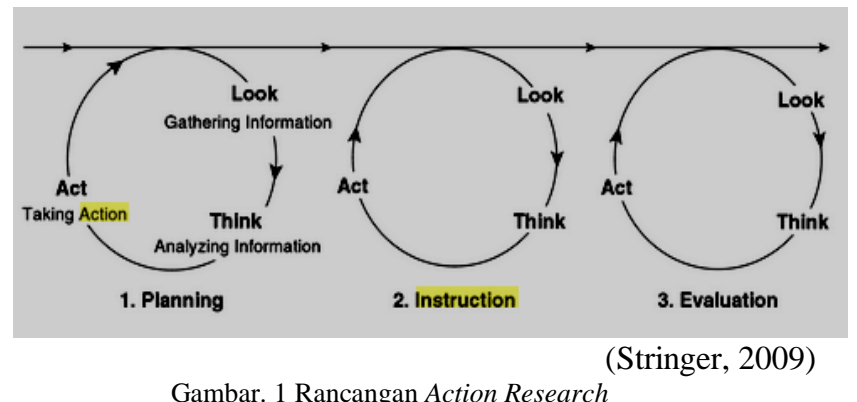

Adapun tahapannya adalah sebagai berikut:

\section{A. Planning}

Menyiapkan segala instrumen penelitian berupa rencana pembelajaran, kisi - kisi tes, pedoman penskoran dan soal tes kemampuan awal mahasiswa dan soal tes akhir. Terdapat 3 materi pokok yang termuat dalam instrumen penelitian yakni bilangan dan operasinya, geometri dan statistik.

\section{B. Instruction}

Melaksanakan pembelajaran yang telah direncanakan. Dalam pembelajaran di kelas, peneliti menggunakan pendekatan literasi matematis dan pendekatan saintifik dengan tahapan pengajuan masalah awal, pemecahan masalah awal dan pemecahan masalah akhir. Dalam proses pemecahan masalah terdapat kemampuan penalaran matematis, koneksi matematis, komunikasi matematis dan representasi matematis.

\section{Evaluation}

Mengevaluasi ketercapaian pembelajaran. Dalam proses ini, peneliti dibantu oleh rekan peneliti lainnya yang tergabung dalam team teaching. Evaluasi ini terdiri atas pengamatan keterlaksanaan pembelajaran, aktivitas mahasiswa dan hasil tes pada setiap akhir pokok materi. Hasil dalam setiap pembelajaran dibahas dan didiskusikan dalam team teaching membahas segala kekurangan guna perbaikan pada pembelajaran berikutnya.

\section{HASIL DAN PEMBAHASAN}

\section{A. Hasil Penelitian}

Dalam penelitian ini digunakan tahapan planning, instruction dan evaluation. Berikut adalah jabaran tahapan pelaksanaan pembelajaran dalam penelitian 
TABEL 1

TAHAPAN PENELITIAN YANG DILAKSANAKAN

\begin{tabular}{|c|c|c|c|}
\hline No & Tahapan & Uraian kegiatan & Hasil \\
\hline Planning & $\begin{array}{l}\text { Think } \\
\text { Act } \\
\text { Look }\end{array}$ & $\begin{array}{l}\text { 1. } \begin{array}{l}\text { Merencanakan } \\
\text { pembelajaran, }\end{array} \\
\text { tes, dll } \\
\text { 2. } \begin{array}{l}\text { Membuat dan } \\
\text { menyusun } \\
\text { tahapan } \\
\text { pembelajaran, } \\
\text { kisi - kisi tes } \\
\text { dan instrumen } \\
\text { lainnya } \\
\text { 3. Memvalidasi } \\
\text { istrumen }\end{array} \\
\end{array}$ & $\begin{array}{l}\text { Instrumen } \\
\text { penelitin }\end{array}$ \\
\hline Instruction & $\begin{array}{l}\text { Think } \\
\text { Act } \\
\text { Look }\end{array}$ & $\begin{array}{l}\text { 4. Merencanakan } \\
\text { dan } \\
\text { mempersiapkan } \\
\text { pelaksanaan } \\
\text { pembelajaran } \\
\text { 5. Melaksanakan } \\
\text { pembelajaran } \\
\text { yang dibantu tim } \\
\text { teaching yang } \\
\text { bertindak sebagai } \\
\text { observer } \\
\text { 6. Bersama dengan } \\
\text { tim teaching } \\
\text { mengevalasi } \\
\text { pelaksanaan } \\
\text { pebelajaran }\end{array}$ & $\begin{array}{l}\text { Pelaksanaan } \\
\text { pembelajaran } \\
\text { berjalan } \\
\text { dengan baik, } \\
\text { aktivitas } \\
\text { mahasiswa } \\
\text { baik (sesuai } \\
\text { dengan } \\
\text { aktivitas } \\
\text { yang } \\
\text { diharapkan } \\
\text { dalam } \\
\text { rencana } \\
\text { pembeajaran) }\end{array}$ \\
\hline Evaluations & $\begin{array}{l}\text { Think } \\
\text { Act } \\
\text { Look }\end{array}$ & $\begin{array}{l}\text { 7. Mengevaluasi } \\
\text { seluruh rangkaian } \\
\text { pembelajaran } \\
\text { untuk melihat } \\
\text { keefektifan setiap } \\
\text { langkah } \\
\text { pembelajaran. } \\
\text { 8. Mengevaluasi } \\
\text { hasil belajar } \\
\text { 9. Jika pelaksanaan } \\
\text { pembelajaran dan } \\
\text { hasil } \\
\text { pembelajaran } \\
\text { belum memenuhi } \\
\text { harapan yang } \\
\text { diinginkan maka } \\
\text { akan diulang } \\
\text { pada pertemuan } \\
\text { berikutnya }\end{array}$ & $\begin{array}{l}\text { Kegiatan } \\
\text { pembelajaran } \\
\text { terlaksana } \\
\text { dengan baik } \\
\text { Kemampuan } \\
\text { literasi } \\
\text { matematis } \\
\text { mahasiswa } \\
\text { meningkat }\end{array}$ \\
\hline
\end{tabular}

Terdapat tiga materi pokok dalam penelitian ini yaitu bilangan dan operasinya, geometri dan pengukuran dan statistik.

Dengan demikian, terdapat 3 kali tes awal dan tiga kali tes akhir pada setiap aspek yang diamati. Kemudin hasil dari tes awal dan tes akhir dihitung rata ratanya. Adapun data hasil dari analisisnya disajikan dalam tabel 2 dan tabel 3 berikut ini :
TABEL 2

NILAI RATA - RATA HASIL TES AWAL LITERASI MATEMATIS MAHASISWA

\begin{tabular}{clc}
\hline No. & Aspek yang diamati & Rata-rata Tes Awal \\
\hline 1 & Pemecahan masalah & 60,3 \\
2 & Komunikasi matematis & 53,2 \\
3 & Penalaran matematis & 47,7 \\
4 & Koneksi matematis & 48,5 \\
5 & Representasi matematis & 42,6 \\
& Rata - rata & $\mathbf{5 0 , 5}$ \\
\hline
\end{tabular}

TABEL 3

NILAI RATA - RATA HASIL TES AKHIR LITERASI MATEMATIS MAHASISWA

\begin{tabular}{clc}
\hline No. & Aspek yang diamati & Rata-rata Tes Akhir \\
\hline 1 & Pemecahan masalah & 78,8 \\
2 & Komunikasi matematis & 76,5 \\
3 & Penalaran matematis & 74,2 \\
4 & Koneksi matematis & 77,6 \\
5 & Representasi matematis & 80,1 \\
& Rata - rata & $\mathbf{7 7 , 4}$ \\
\hline
\end{tabular}

\section{B. Pembahasan}

Secara umum tujuan penelitian ini adalah meningkatkan literasi matematis mahasiswa calon guru sekolah dasar dalam membelajarkan matematika sekolah dasar. Subjek dalam penelitian ini adalah seluruh mahasiswa program studi pendidikan guru sekolah dasar semester I pada mata kuliah Konsep Dasar Matematika Sekolah Dasar. Penelitian ini merupakan penelitian tindakan dengan fokus pelaksanaan pembelajaran di kelas.

Secara umum tujuan penelitian ini adalah meningkatkan literasi matematis mahasiswa calon guru sekolah dasar dalam membelajarkan matematika sekolah dasar. Subjek dalam penelitian ini adalah seluruh mahasiswa program studi pendidikan guru sekolah dasar semester I pada mata kuliah Konsep Dasar Matematika Sekolah Dasar. Penelitian ini merupakan penelitian tindakan dengan fokus pelaksanaan pembelajaran di kelas.

Pelaksanaan penelitian dimulai dari minggu pertama bulan bulan Agustus 2018 sampai dengan minggu pertama bulan Januari 2019. Terdapat tiga tahap utama dalam penelitian ini yaitu planning, instruction dan evaluation. Dalam tahap planning terdapat think (merencanakan pembelajaran, tes, dll), act (membuat dan menyusun tahapan pembelajaran, kisi - kisi tes dan instrumen lainnya), look (memvalidasi istrumen yang telah dibuat agar siap digunakan).

Setelah tahap planning dilakukan, selanjutya masuk pada tahap istruction. Dalam tahapan ini terdapat think (merencanakan dan mempersiapakan pelaksanaan pembelajaran), act (melaksanakan pembelajaran yang dibantu tim teaching yang bertindak sebagai observer), dan look (bersama dengan tim teaching mengevalasi pelaksanaan pebelajaran). Dari hasil tahap istruction diketahui bahwa pelaksanaan pembelajaran berjalan dengan baik sesuai degan perencanaan dan aktivitas mahasiswa pun tidak didapati 


\section{- - - Jurnal Pendidikan Matematika Indonesia \\ Volum 4 Nomor 1 bulan Maret. Page 42 - 46 \\ p-ISSN: 2477-5967 e-ISSN: 2477-8443}

melakukan aktivitas yang kurang relevan dalam pembelajaran.

Tahapan berikutnya adalah evaluation (evaluasi). Pada tahap ini, evaluasi dilakukan secara menyeluruh baik pada seluruh rangkaian pelaksanaan pebelajaran maupun evaluasi hasil belajar. Untuk evaluasi hasil belajar, dilakukan sebanyak dua kali pada setiap materi pokok pembelajaran yakni tes kemampuan awal (dilakukan sebelum pelaksanaan pembelajaran) dan tes akhir (tes setelah pembelajaran).

Dalam pelaksanaan pembelajaran di kelas, peneliti menggunakan pendekatan literasi matematis dengan tahapan yakni diawali dengan menyajikan masalah, kemudian mahasiswa diminta untuk mengidentifikasi serta mengkomunikasikan sesuai dengan pemahamannya, menemukan ide pokok atau hal - hal penting dari masalah yang disajikan dalam masalah sehingga dapat merencanakan penyelesaian masalah tersebut, dalam melaksanakan penyelesaian masalah mahasiswa mampu mengkoneksikan/mengaitkan berbagai konsep matematis, serta mampu menyajikan masalah maupun penyelesaiannya dalam bentuk gambar, grafik, tabel dan sebagainya.

Berdasarkan hasil penelitian dan analisis data hasil penelitian, diperoleh bahwa kemampuan literasi matematis mahasiswa cenderung mengalami peningkatan. Hal ini terlihat dari tes hasil kemampuan mahasiswa ketika disajikan berbagai masalah matematis, mahasiswa sudah mampun mengidentifikasi serta mengkomunikasikan ide - ide pokok permasalahan, merencanakan penyelesaian masalah serta menerapkan perencanaan meskipun terdakang terdapat kekeliruan dalam proses kalkulasi. Meskipun demikian secara bertahap hal tersebut dapat teratasi.

Untuk kemampuan pemecahan masalah pada tes awal diperoleh rata - rata hasil tes adalah 60,3 sedangkan rata rata untuk tes akhir adalah 78,8 ini berarti terjadi peningkatan kemampuan rata - rata sebesar 18,5. Adapun indikator yang menunjukkan bahwa mahasiswa telah memiliki kemampuan meliterasi matematis seperti kemampuan pemecahan masalah adalah: (1) Mampu menerapkan dan mengadaptasi berbagai pendekatan dan strategi untuk menyelesaikan masalah, (2) Menyelesaikan masalah yang muncul di dalam matematika atau di dalam konteks lain yang melibatkan matematika, (3) Membangun pengetahuan matematis yang baru lewat pemecahan masalah, dan (4) Memonitor dan merefleksi pada proses pemecahan masalah matematis (NCTM, 2003).

Sedangkan untuk kemampuan komunikasi matematis, pada tes awal diperoleh rata - rata hasil tes adalah 53,2 sedangkan rata - rata untuk tes akhir adalah 76,5 ini berarti terjadi peningkatan kemampuan rata - rata sebesar 23,3. Dengan indikator mahasiswa mampu mengkomunikasikan pemikiran matematika mereka secara koheren dan jelas kepada teman sebaya atau orang lain, dapat menggunakan bahasa matematika untuk mengekspresikan ide secara tepat, mampu menganalisis dan mengevaluasi pemikiran matematika dan strategi lainnya (NCTM, 2003).

Untuk kemampuan penalaran matematis, pada tes awal diperoleh rata - rata hasil tes adalah 47,7 sedangkan rata rata untuk tes akhir adalah 74,2 ini berarti terjadi peningkatan kemampuan rata - rata sebesar 26,5. Adapun indikatornya adalah mahasiswa dapat menjelaskan alasan dan bukti sebagai aspek fundamental matematika, mengembangkan dan mengevaluasi argumen dan bukti matematika, dapat memilih dan menggunakan berbagai jenis penalaran dan metode pembuktian (NCTM, 2003).

Kemampuan koneksi matematis, pada tes awal diperoleh rata - rata hasil tes adalah 48,5 sedangkan rata - rata untuk tes akhir adalah 77,6 ini berarti terjadi peningkatan kemampuan rata - rata sebesar 29,1 dengan indikator mahsiswa dapat mengenali dan menggunakan koneksi antara ide-ide matematika, mengenali dan menerapkan matematika dalam konteks di luar matematika, dapat menunjukan bagaimana ide-ide matematika saling berhubungan dan membangun satu sama lain (NCTM, 2003).

Sedangkan untuk kemampuan representasi matematis, pada tes awal diperoleh rata - rata hasil tes adalah 42,6 sedangkan rata - rata untuk tes akhir adalah 80,1 ini berarti terjadi peningkatan kemampuan rata - rata sebesar 37,5. Adapun indikator kemampuan yang diperoleh adalah mahasiswa dapat melakukan pemodelan matematis, membuat dan menggunakan representasi untuk mengatur, merekam, dan berkomunikasi ide ide matematis, mahaiswa dapat memilih, menerapkan, dan menterjemahkan representasi matematis untuk menyelesaikan masalah (NCTM, 2003).

Peningkatan kemampuan literasi matematis mahasiswa secara keseluruhan adalah 26,9 dengan rata - rata tes akhir adalah 77,4 termasuk dalam kategori B (baik). Hal ini dikarenakan pembelajaan berbasis literasi matematis mampu menopang dan membiasakan para peserta didik untuk meliterasi matematika. Literasi matematika menjadikan seseorang untuk merumuskan, mengunakan dan menafsirkan matematika dalam berbagai konteks masalah kehidupan sehari-hari secara efisien (Sari, 2015). Selain itu juga dengan literasi matematis dapat menjadikan matematika menjadi 'hidup' dan bermanfaat (Johar 2012).

\section{KESIMPULAN}

Berdasarkan hasil penelitan dan pembahasan, maka dapat disimpulkan bahwa; Berdasarkan hasil analisis data dapat disimpulkan bahwa (1) kemampuan literasi matematis awal mahasiswa masih rendah dengan rata-rata hasil tes 50,$5 ;(2)$ pembelajaran matematika berbasis literasi berjalan dengan baik; (3) terdapat peningkatan kemampuan literasi matematis mahasiswa sebesar 26,9 ; (4) pembelajaran matematika berbasis literasi berkontribusi terhadap kemampuan literasi matematis mahasiswa.

\section{DAFTAR PUSTAKA}

Bistari. (2015). Mewujudkan Penelitian Tindakan Kelas. Pontianak: PT. Ekadaya Multi Inovasi

Indonesia, Presiden Republik. Undang-Undang Republik Indonesia nomor 20 tahun 2003 tentang Sistem pendidikan nasional. Jakarta: Pemerintah Republik Indonesia, 2003. 
Johar, R. (2012). Domain Soal PISA untuk Literasi Matematika. Jurnal Peluang, 1(1), 30.

Kenedi dan Helsa. (2017). Literasi Matematis Dalam Pembelajaran Berbasis Masalah. Prosiding Seminar Nasional Pendidikan Guru Sekolah Dasar, Universitas Negeri Padang \& Himpunan Dosen PGSD Indonesia, 4, 5, 6 september 2017. ISBN: 978602-619994-0-4 .

NCTM. (2000). Principles and Standards for School Mathematics. United States: NCTM

NCTM. (2003). Standards for Secondary Mathematics Teacher. United States of America : The National Council of Teachers of Mathematics, Inc.

OECD. (2016). PISA 2015 Results in Focus. New York: Columbia University

Tjalla, A. (2010). Potret Mutu Pendidikan Indonesia Ditinjau dari Hasil-hasil Studi Internasional. Paper (diterbitkan)
Sari, R. H. N. (2015, November). Literasi Matematika: Apa, Mengapa, dan Bagaimana. In Prosiding Seminar Nasional Matematika dan Pendidikan Matematika $U N Y$ (p. 714)

Suherman dkk. 2003. Strategi Pembelajaran Matematika Kontemporer. Bandung: PT Remaja Rosdakarya.

Sugiyono, A. 2015. Metode Penelitian Kuantitatif Kualitatif dan $R \& D$. Jakarta: Raja Grafindo Persada

Sukardi, H.M. (2015). Metode Penelitian Tindakan Kelas. Jakarta: Bumi Aksara

Stringer Ernest T. (2009). Integrating Teaching, Learning and Action Research. United Stated: Sage Publications

Tampubolon Saur. (2013). Penelitian Tindakan Kelas Sebagai Pengembangan Profesi Pendidik dan Keilmun. Jakarta: Erlangga 